\title{
Identification and Quantification of Carbonate Species Using Rock-Eval Pyrolysis
}

\author{
D. Pillot ${ }^{1}$, E. Deville ${ }^{1 *}$ and A. Prinzhofer ${ }^{1,2}$ \\ 1 IFP Energies nouvelles, 1-4 avenue de Bois-Préau, 92852 Rueil-Malmaison Cedex - France \\ 2 Present adress: IPEXCO Rua Dezenove de Fevereiro, 69-71 Botafogo, Rio de Janeiro, R, CEP 22.280-030 - Brazil \\ e-mail: daniel.pillot@ifpen.fr - eric.deville@ifpen.fr - alain.prinzhofer@ipexco.com.br \\ * Corresponding author
}

\begin{abstract}
Résumé - Détermination et quantification des carbonates par pyrolyse Rock-Eval - Cet article présente une nouvelle méthode fiable et rapide pour caractériser et quantifier les carbonates dans tout type d'échantillon solide. La méthode est basée sur la quantification du flux de $\mathrm{CO}_{2}$ émis lors de la décomposition thermique progressive des carbonates au cours d'un chauffage programmé. Les différents pics de déstabilisation permettent la détermination des différents types de carbonates présents dans l'échantillon analysé. La quantification de chaque pic donne les proportions respectives de ces différents types de carbonate présents dans l'échantillon. La procédure qui a été choisie dans ce travail utilise un pyrolyseur Rock-Eval 6 standard en mode oxydation. Des profils caractéristiques d'échantillons de références sont présentés pour les carbonates naturels les plus courants. Cette méthode devrait permettre différents types d'application dans des disciplines diverses et dans des domaines à la fois académiques et industriels.
\end{abstract}

\begin{abstract}
Identification and Quantification of Carbonate Species Using Rock-Eval Pyrolysis - This paper presents a new reliable and rapid method to characterise and quantify carbonates in solid samples based on monitoring the $\mathrm{CO}_{2}$ flux emitted by progressive thermal decomposition of carbonates during a programmed heating. The different peaks of destabilisation allow determining the different types of carbonates present in the analysed sample. The quantification of each peak gives the respective proportions of these different types of carbonates in the sample. In addition to the chosen procedure presented in this paper, using a standard Rock-Eval 6 pyrolyser, calibration characteristic profiles are also presented for the most common carbonates in nature. This method should allow different types of application for different disciplines, either academic or industrial.
\end{abstract}

\section{INTRODUCTION}

The characterisation and quantification of carbonates in solids is required by a wide range of activities. In geoscience, identification of carbonates is instrumental for carbonate geology (including sedimentology, metallogeny and diagenesis), for petroleum geoscience (in order to characterise source rocks, reservoirs and seals) and for underground storage of acid gases such as $\mathrm{CO}_{2}$ or $\mathrm{H}_{2} \mathrm{~S}$ (in order to assess the impact of these gases on the pre-existing carbonates, if any, of the receiving reservoir). Carbonate analysis and quantification is also useful in soil science for characterisation and subsequent agricultural purposes. It is also useful in various additional industrial domains including iron smelting, cement and lime manufacture, production of ceramic glazes, drilling industries (quality of the cements) and building (quality of the construction rocks).

Semi-quantitative determination of carbonates can commonly be done using classical optical methods (such as 
an optic microprobe on thin sections) or X-ray diffraction (Diebold et al., 1963; Gavish and Friedman, 1973; Weber, 1968; Roselle, 1982; Martinez and Plana, 1987; Hillier et al., 2001; Al Jaroudi et al., 2007) or by a group of different analytical methods (such as Scanning Electron Microscope, electron microprobe, infrared or Raman spectroscopy, chemical analysis, etc.). Nevertheless, the real quantification of carbonates, especially in the case of mixing of different carbonates in the same sample, is not such an easy task and, to date, only a few methods allowing one to directly quantify the carbonate content in samples of rocks or other solid materials are available. Classical methods of calcimetry by acid attack and gravimetry or measurement of the released $\mathrm{CO}_{2}$ (Scheibler method, ÖNORM, 1999), or else Fourier Transform InfraRed (FT-IR) (Legodi et al., 2001; Bosch et al., 2002; Boke et al., 2004; Vagenas et al., 2003; Tatzber et al., 2007) spectroscopy can be used in the case of occurrence of a single carbonate family in the sample, especially calcium carbonate, but the quantification in cases of mixing of different carbonates requires relatively time-consuming studies such as thermogravimetry (Cebulak et al., 2003; Siewert, 2004; Villain et al., 2007), SEM mapping or microprobe mapping, or wholerock analyses with processing of the results. Methods based on X-ray diffraction allow a good determination of the different types of carbonates but these methods allow only a semi-quantitative estimate of the proportions of the different carbonates.

However, all these methods mentioned above require a relatively long chain of data acquisition and processing and some of them need expensive devices. To the best of the authors' knowledge, to date, there is no available method to quickly determine and directly quantify the entire family of carbonates in solid samples. In this paper, we present a simple and rapid method for determination and quantification of the carbonates in solid samples which is based on the thermal decomposition of the different carbonates during a programmed heating and on the monitoring of the released $\mathrm{CO}_{2}$ during the decomposition.

Using the Rock-Eval ${ }^{\circledR}$ pyrolyser, previous published works have already shown how it is possible to quantify the amount of calcium carbonates provided that the carbonates present in the samples are only calcium carbonates (Lafargue et al., 1998). This method is thus not applicable when we are dealing with other carbonates (such as dolomite, siderite, magnesite and other carbonates less common in nature). The aim of this paper is to complete this approach using RockEval pyrolysis techniques to allow the characterisation and quantification of the different types of carbonates in any types of solid samples and in a relatively short time (about 30 minutes with the chosen procedure).

\section{METHOD PRINCIPLES}

This method ${ }^{\circledR}$ (Pillot et al., 2011), which allows characterising and quantifying carbonates in powder of all types of solid samples (rocks, soils, cements, etc.) with relatively small samples (from $10 \mathrm{mg}$ to $300 \mathrm{mg}$, preferentially $>40 \mathrm{mg}$ ), consists of measuring the $\mathrm{CO}_{2}$ emitted by a sample when it is thermally decomposed during a monitored heating. For instance, the thermal destabilisation of calcite $\left(\mathrm{CaCO}_{3}\right)$ produces the following reaction:

$$
\mathrm{CaCO}_{3} \rightarrow \mathrm{CaO}+\mathrm{CO}_{2}
$$

Because the different families of carbonates are destabilised at different temperatures, it is possible to deduce their nature according to their decomposition temperature and because carbonates emit $\mathrm{CO}_{2}$ during their destabilisation, it is possible to quantify the amount of carbonate initially present in the sample after a complete thermal decomposition. It is also possible to distinguish carbonates and organic matter, because when carbonates are thermally decomposed with a flux of air (input of oxygen), they do not produce $\mathrm{CO}$, whereas oxidation of organic matter produces $\mathrm{CO}$ and $\mathrm{CO}_{2}$ by combustion in the presence of oxygen.

For this study, we used a classical Rock-Eval $6^{\circledR}$ (Lafargue et al., 1998) to develop a systematic analytical procedure. The method is based on a combustion of the sample using specifically the oxidation cycle of the Rock-Eval 6. A prior pyrolysis as is done in a standard run is not mandatory but it provides complementary useful information about the organic matter present in the samples. For the determination and quantification of the carbonates using the oxidation mode, the samples are heated according to a programmed temperature ramp in an oven flushed with a continuous flux of air (carrier gas to the analysers). This allows a thermal

TABLE 1

Typical values for the temperature peak of the different carbonates versus the weight of the samples

\begin{tabular}{c|c|c|c|c|c|c|c|c|c|c}
\hline Weight (mg) & Azurite & Malachite & Siderite & Rhodochrosite & Magnesite & Dolomite peak1 & Dolomite peak2 & Aragonite & Chalk & Marble \\
\hline 5 & 416 & & 515 & 652 & 602 & & 765 & 762 & 776 & 780 \\
\hline 10 & 413 & 382 & 516 & 650 & 613 & & 790 & 788 & 801 & 805 \\
\hline 20 & 408 & 388 & 516 & 647 & 622 & 797 & 817 & 819 & 835 & 837 \\
\hline 40 & & 393 & 519 & 647 & 631 & 822 & 831 & 838 & 850 & 850 \\
\hline
\end{tabular}




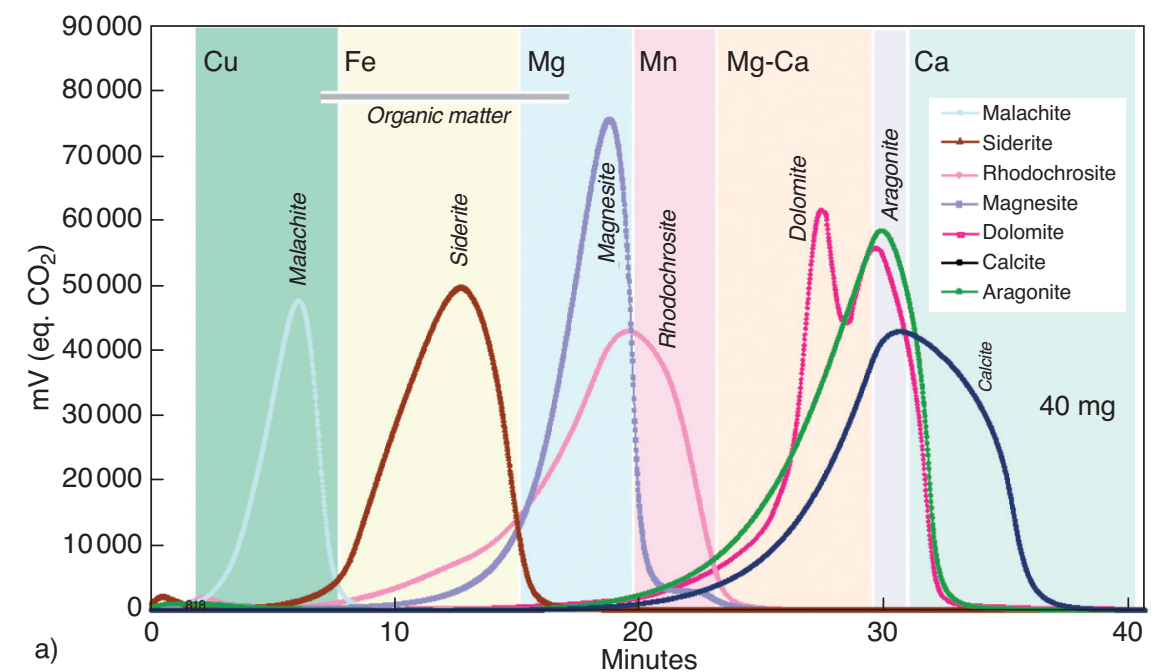

a)

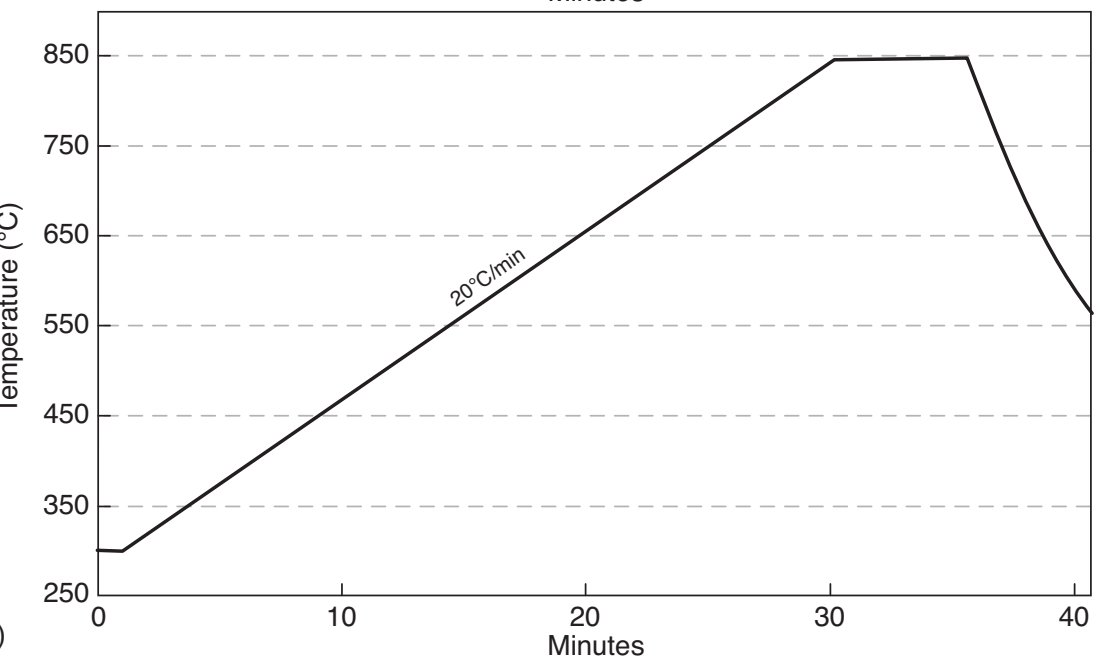

Figure 1

Examples of characteristic peaks a) obtained with $40 \mathrm{mg}$ of different pure mineral standards (malachite, siderite, magnesite, rhodochrosite, dolomite, aragonite, calcite), b) with a heating ramp of $20^{\circ} \mathrm{C} / \mathrm{min}$ between 300 and $850^{\circ} \mathrm{C}$.

decomposition of the carbonates which is monitored by analysing the produced gas with an analyser (infrared spectrometer) giving a continuous measurement of the amount of $\mathrm{CO}_{2}$ as a function of temperature and time. The oxidation oven heats the samples in the range $300^{\circ} \mathrm{C}$ to $850^{\circ} \mathrm{C}$ with a preset temperature programme. The Rock-Eval 6 device is limited to $850^{\circ} \mathrm{C}$ but heating at slightly higher values would be very useful, especially for the study of calcite because this mineral is destroyed at the upper limit of the temperature capability of the Rock-Eval 6 (Fig. 3c,d). With the new version of the Rock-Eval (7), it will be possible to heat up to $1200^{\circ} \mathrm{C}$ and so this specific problem concerning calcium carbonates will be resolved. However, even with the Rock-Eval 6, calcite is fully destroyed after the run and so the quantification is correct. It is just the temperature value of the peak which is imposed by the temperature at the end of the heating ramp. In all the experiments shown here, we chose a constant standard temperature ramp of $20^{\circ} \mathrm{C}$ per minute in order to be able to reliably compare the different results.

\section{CHARACTERISATION OF CARBONATES}

\subsection{Procedure}

During heating, carbonates destabilise and give a characteristic profile of $\mathrm{CO}_{2}$ depending on the temperature of thermal destabilisation of the different carbonate minerals. For each individual carbonate mineral, the pattern of $\mathrm{CO}_{2}$ shows one or 

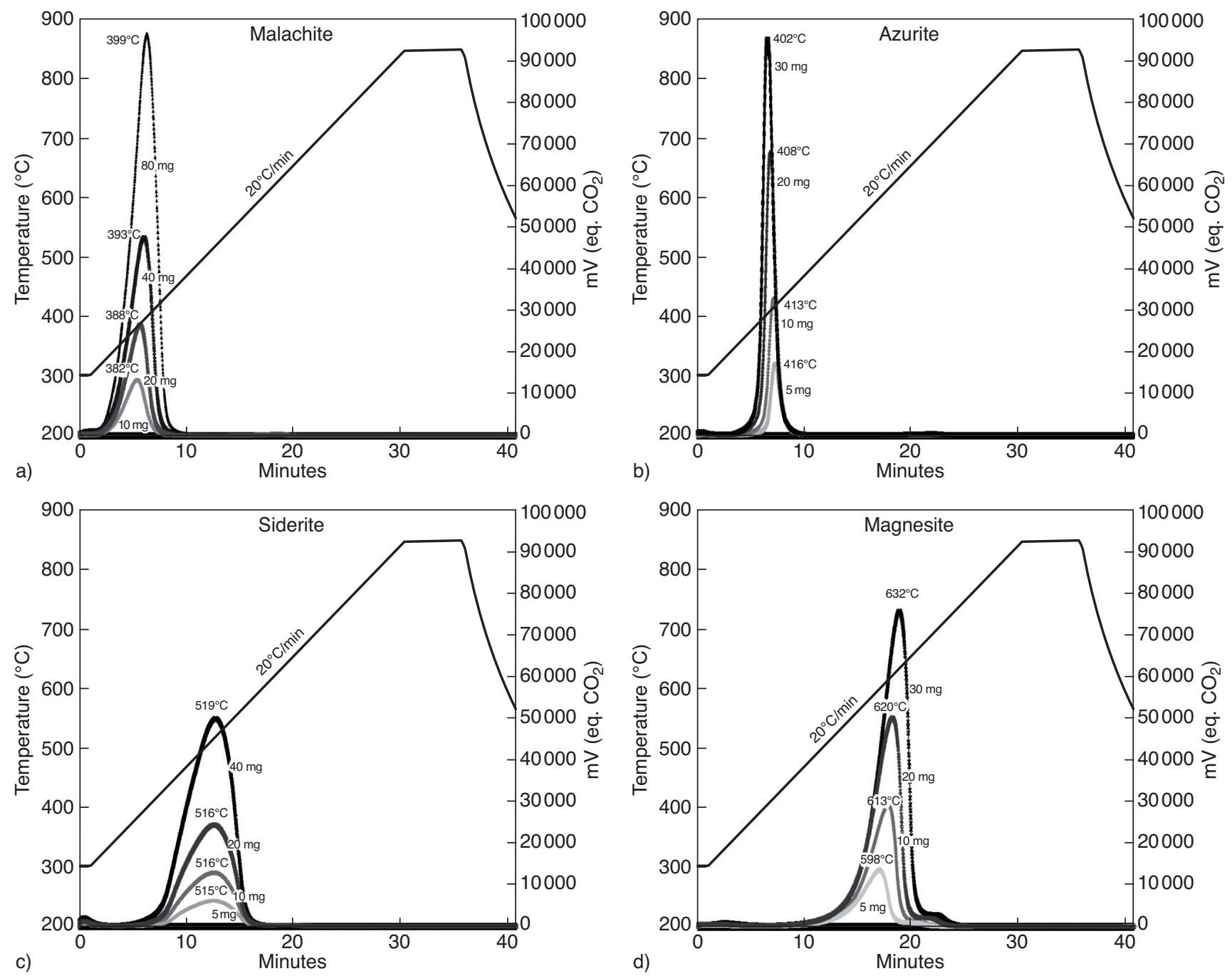

Figure 2

Monitored thermal destabilisation of a) malachite (Morocco); b) azurite (Morocco); c) siderite (Greenland); d) magnesite (Oman).

several peaks. The different types of carbonates are identifiable by the temperature and the shape of the peaks (notably height and area of the peaks). This profile is a unique fingerprint and characterises each type of carbonate within the sample. With this signature, it is possible to discriminate all the types of carbonates present in the sample, such as calcium carbonate (calcite, aragonite), magnesium carbonate (magnesite, hydromagnesite), iron carbonate (siderite), manganese carbonate (rhodochrosite), copper carbonates (azurite, malachite), mixed carbonates (dolomite, ankerite, etc.) and all other types of carbonates rare in nature. It also allows easily distinguishing mixture of carbonates. As mentioned before, complementary to the $\mathrm{CO}_{2}$ recording, $\mathrm{CO}$ measurement allows distinguishing carbon from organic matter (the combustion of organic matter emits $\mathrm{CO}$ which is not the case during carbonate destabilisation; Lafargue et al., 1998).
Reference carbonate samples were used to provide reference $\mathrm{CO}_{2}$ profiles. The reference profiles have characteristic peaks, each peak being associated with the type of carbonate identified. It is thus possible to determine the type of carbonate in any kind of sample by comparison with these reference profiles.

To calibrate the reference profiles, we selected rocks containing only one carbonate and known proportions of this carbonate, preferentially pure minerals (pure calcite, pure aragonite and so on). Figure 1 compares the characteristic destabilisation profiles of different carbonates for the same weight of analysed material $(40 \mathrm{mg})$ and for the same heating ramp $\left(20^{\circ} \mathrm{C} / \mathrm{mn}\right)$. Globally, at increasing temperature, $\mathrm{Cu}-$ carbonates destabilise first, then Fe-carbonates, then $\mathrm{Mg}$ and Mn-carbonates and finally Ca-carbonates (Fig. 1-3). 

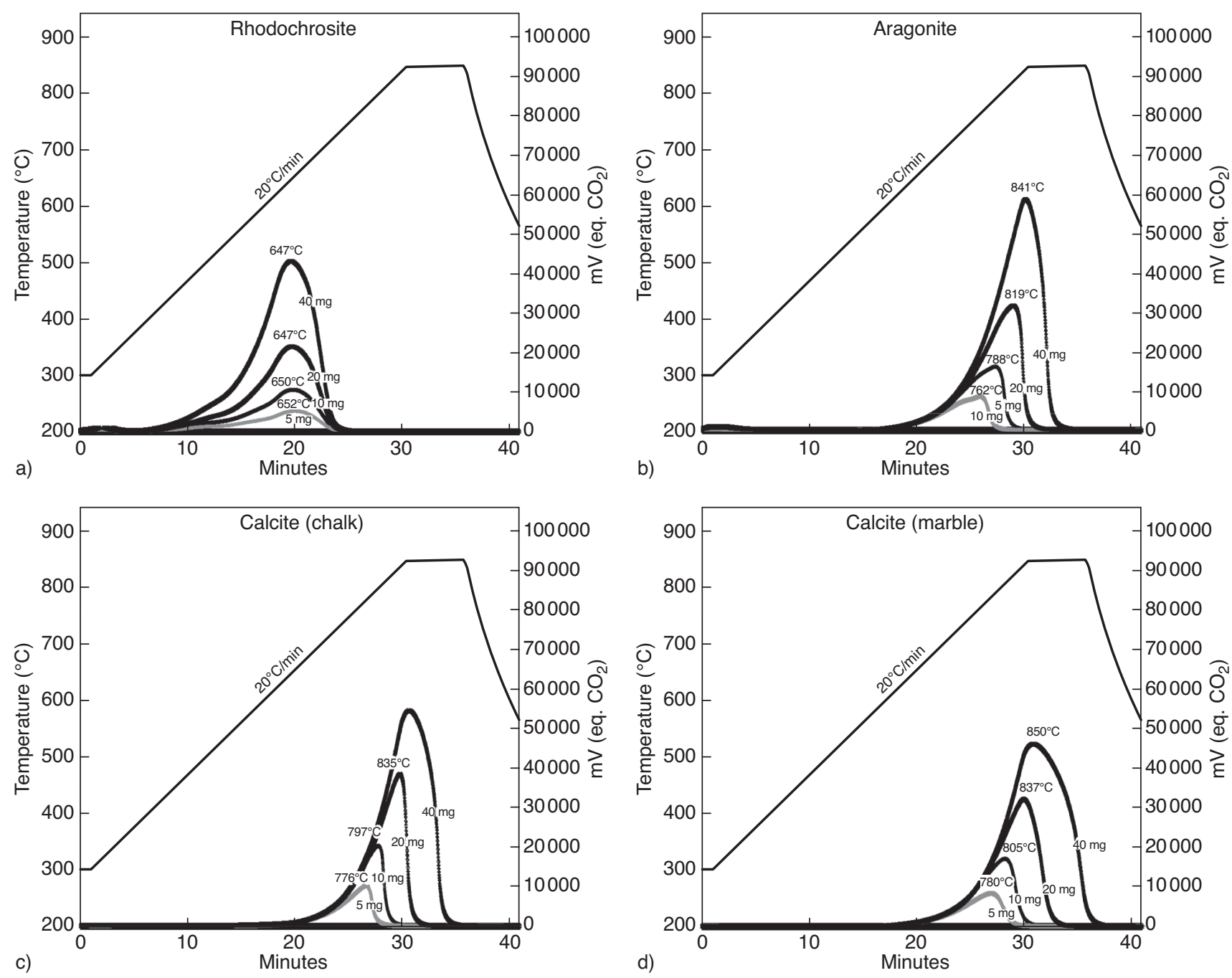

Figure 3

Monitored thermal destabilisation of a) rhodochrosite (Colorado); b) aragonite (Lambi shell from Guadeloupe, France); c) calcite (chalk from the Paris basin, France); d) calcite (marble from Paros, Greece).

\subsection{Simple and Complex Carbonates}

Simple carbonates such as siderite $\left(\mathrm{FeCO}_{3}\right)$, magnesite $\left(\mathrm{MgCO}_{3}\right)$, rhodochrosite $\left(\mathrm{MnCO}_{3}\right)$, aragonite $\left(\mathrm{CaCO}_{3}\right)$ and calcite $\left(\mathrm{CaCO}_{3}\right)$ show a single decomposition peak (Fig. 2, 3), whereas complex carbonates (carbonate of several elements) such as dolomite $\left(\mathrm{MgCa}\left(\mathrm{CO}_{3}\right)_{2}\right)$ and ankerite $(\mathrm{Ca}(\mathrm{Fe}, \mathrm{Mg}$, $\mathrm{Mn})\left(\mathrm{CO}_{3}\right)_{2}$ ) show several decomposition peaks (Fig. 4). Simple carbonates linked with hydroxide anions also show a single peak. For instance, malachite $\left(\mathrm{Cu}_{2}\left(\mathrm{CO}_{3}\right)(\mathrm{OH})_{2}\right)$ and azurite $\left(\mathrm{Cu}_{2}\left(\mathrm{CO}_{3}\right)_{2}(\mathrm{OH})_{2}\right)$ show just one peak (Fig. 2). Hydrated carbonates such as hydromagnesite $\left(\mathrm{Mg}_{5}\left(\mathrm{CO}_{3}\right)_{4}(\mathrm{OH})_{2}\right.$, $4 \mathrm{H}_{2} \mathrm{O}$ ) show several peaks (Fig. 4). For the same weight of sample, the height and width of the peaks vary in function of the composition of each specific mineral.

\subsection{Mass Effect}

With the adopted procedure and the device that we used (Rock-Eval 6), we observed a mass effect characterised by an influence of the mass of the analysed sample on the peak temperature of the same reference sample, whereas all the samples were thinly crushed according to the same procedure with a laboratory crusher. The amplitude of this effect depends on the different carbonate types and it corresponds to a shift of temperature of the maximal release of $\mathrm{CO}_{2}$. This effect is notably observed for small samples and it tends to disappear for all carbonate samples around $40 \mathrm{mg}$ (Fig. 2-5). On the other hand, over $40 \mathrm{mg}$, we observed a saturation effect of the cell of the Rock-Eval for some carbonates, notably for magnesite (due to sudden high flux of $\mathrm{CO}_{2}$ ). It is 

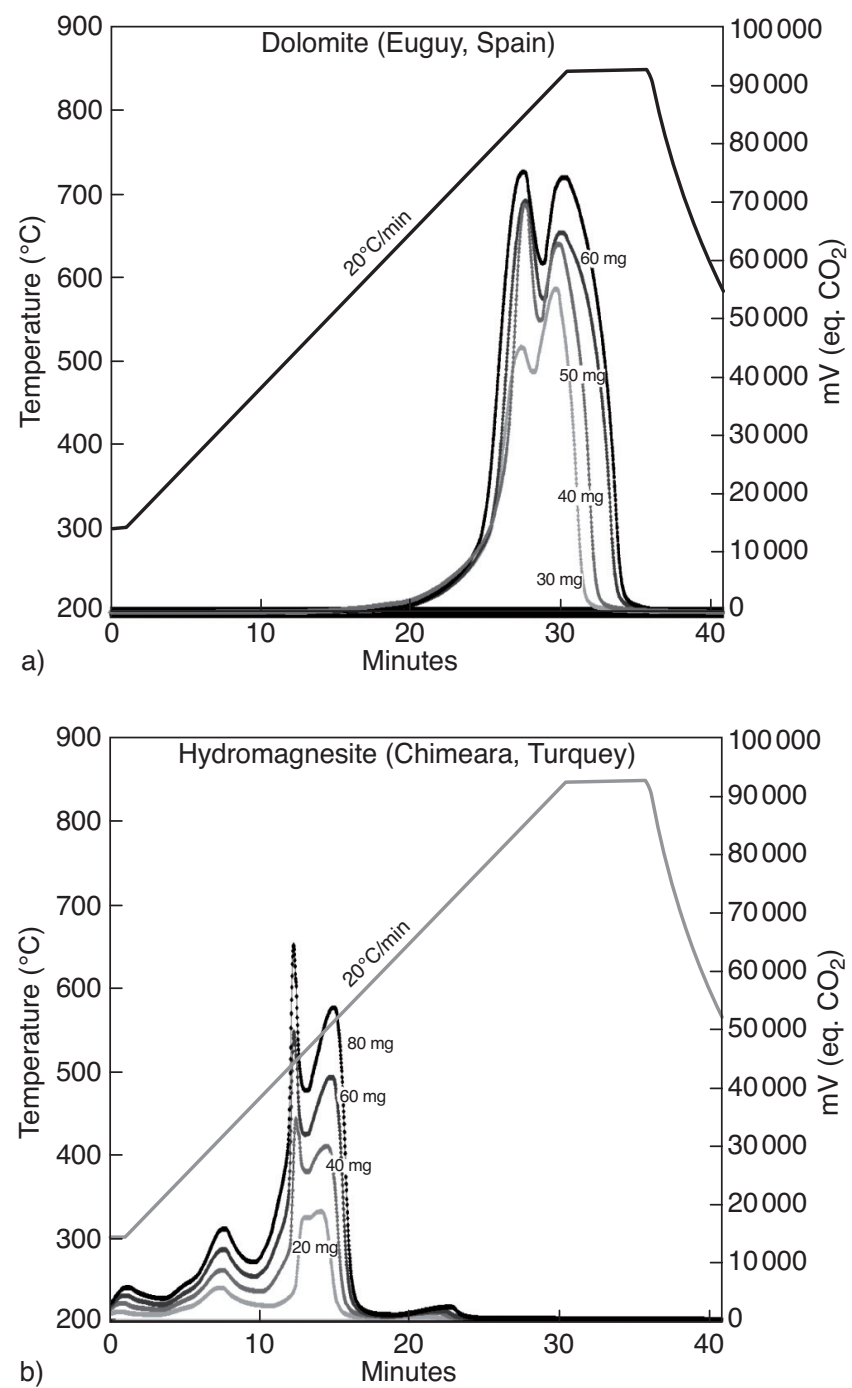

Figure 4

Monitored thermal destabilisation of a) dolomite pure crystal from Euguy (Spain); b) hydromagnesite (Chimaera, Turkey).

thus preferable to proceed with samples of weight close to $40 \mathrm{mg}$ to optimise the reliability of the determination and quantification, but in cases where only small samples are available, it is necessary to take into account this effect (see chart shown in Fig. 5). Also, as we already mentioned above, the analyser we used does not allow one to monitor hightemperature thermal decomposition $\left(>850^{\circ} \mathrm{C}\right)$, which is a limiting factor for a good definition of the calcite peaks which are higher than $850^{\circ} \mathrm{C}$ for samples $>20 \mathrm{mg}$ (Fig. 2, 6).

\subsection{Crystallisation Effect}

The size of the mineral growths very probably also has an effect in terms of thermal destabilisation of some carbonates.

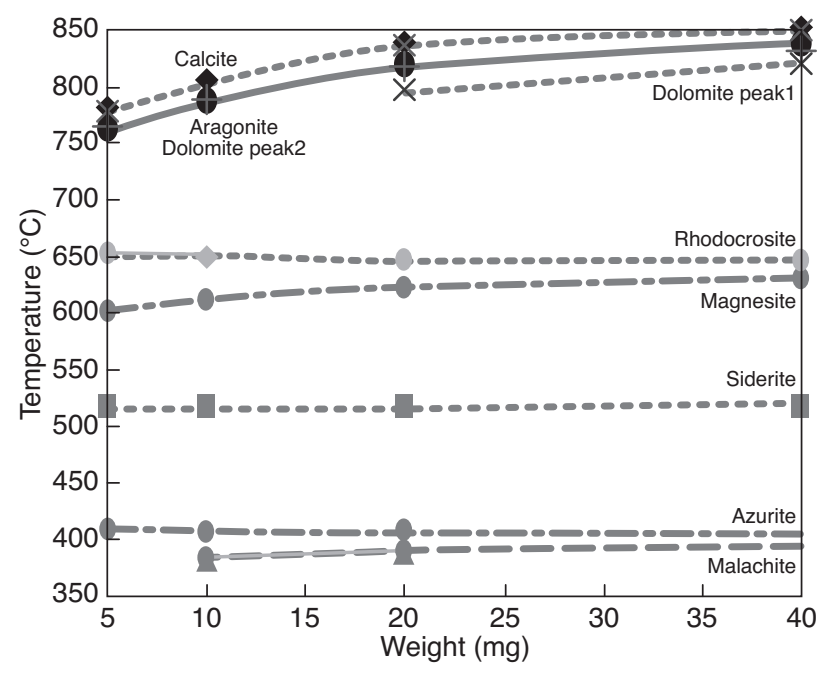

Figure 5

Simplified chart illustrating the mass effect on the determination of the peak of decomposition of the different carbonates using a Rock-Eval 6. For samples heavier than $40 \mathrm{mg}$ this mass effect is negligible.

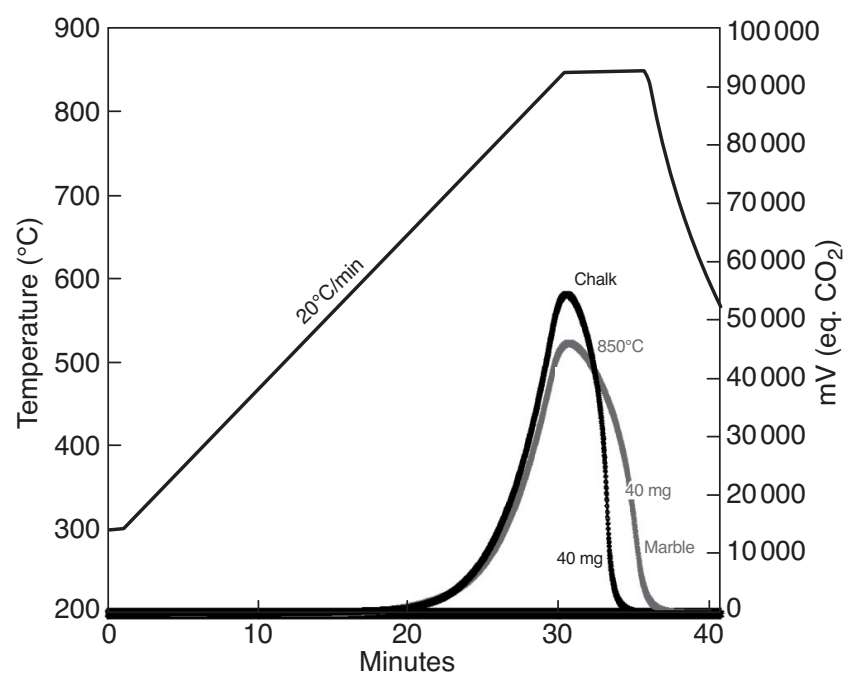

Figure 6

Compared monitored thermal destabilisation of chalk and marble.

This phenomenon is very moderate for most carbonates but it is clear for the case of calcite. Small calcite minerals destabilise more easily than large calcite minerals. For instance, chalk destabilises at a lower temperature than marble. Figure 6 illustrates an example of the difference in shape of the respective destabilisation profiles. The destabilisation profile of chalk is relatively similar to that of aragonite (slightly higher temperature), whereas the destabilisation profile of a metamorphic marble extends to higher temperatures (Fig. 6). In this example, for the case of marble, the strong asymmetry 


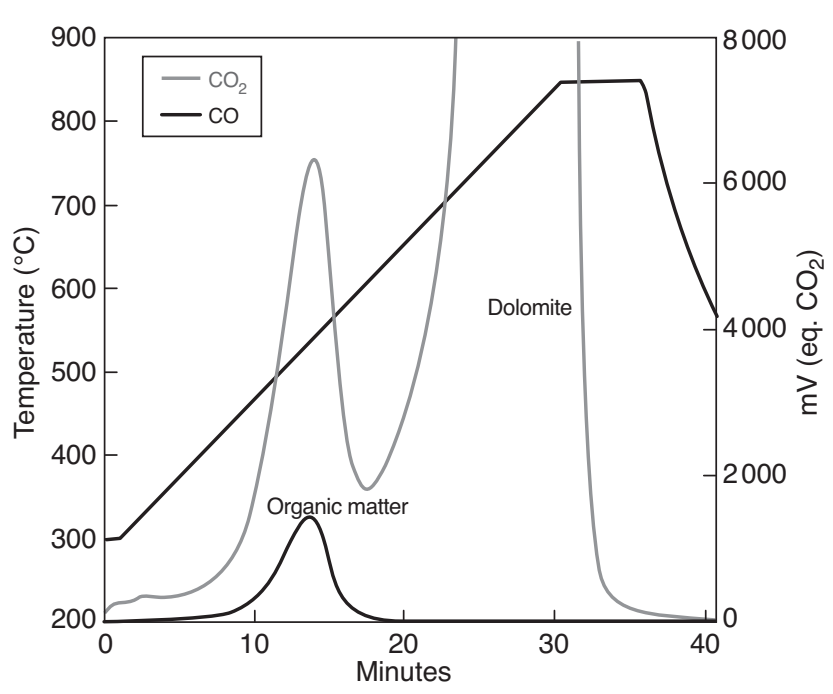

Figure 7

This figure shows an example of the presence of organic matter associated with carbonate (here dolomite). During the Rock-Eval oxidation cycle the combustion of the organic matter produces $\mathrm{CO}$ and $\mathrm{CO}_{2}$, whereas the thermal decomposition of carbonate produces only $\mathrm{CO}_{2}$.

and the highest value of the peak of temperature is imposed by the heating ramp which is limited to $850^{\circ} \mathrm{C}$. As mentioned above, this problem will not remain with the new Rock-Eval 7 with which it will be possible to have a heating ramp up to a temperature of $1200^{\circ} \mathrm{C}$.

\subsection{Organic Matter Effect}

The occurrence of organic matter associated with carbonates can be easily detected using Rock-Eval 6 (Lafargue et al., 1998). During the oxidation cycle the combustion of organic matter produces $\mathrm{CO}$ and $\mathrm{CO}_{2}$, whereas the decomposition of carbonates (without organic matter) produces only $\mathrm{CO}_{2}$. Figure 7 shows an example of how we can distinguish the occurrence of organic matter associated with carbonate $\left(\mathrm{CO}_{2}\right.$ and $\mathrm{CO}$ peaks for organic matter and only a $\mathrm{CO}_{2}$ peak for carbonate). In the specific case of an interference with $\mathrm{CO}_{2}$ released by organic matter (i.e. for copper carbonates, siderite and magnesite), it is necessary to conduct a classical Rock-Eval run (pyrolysis and oxidation) which allows one to correctly distinguish organic matter and carbonates.

\section{QUANTIFICATION OF THE CARBONATE CONTENT}

\subsection{Principle}

The content of the different types of carbonates can be easily quantified from the surface area of each characteristic peak provided by the thermal destabilisation of each carbonate present in the sample. For this, we compare the surface area of the peak of $\mathrm{CO}_{2}$ of a reference sample containing a known proportion of carbonate with the peak of $\mathrm{CO}_{2}$ of the analysed sample. This allows one to directly deduct the content of the different carbonates present in the sample analysed operating according to a constant procedure. The $\mathrm{CO}_{2}$ content of the analysed sample is given by:

$$
\mathrm{CO}_{2} \text { sample }=\mathrm{CO}_{2} \text { ref }[\mathrm{RFi} / \text { RFref }]
$$

- $\mathrm{CO}_{2}$ ref: $\mathrm{CO}_{2}$ content emitted by a reference sample;

- RFi: response factor $\left(\mathrm{CO}_{2}\right.$ equivalent) of the analysed sample;

- RFref: response factor $\left(\mathrm{CO}_{2}\right.$ equivalent $)$ of the reference sample.

The response factors are expressed in millivolts $(\mathrm{mV})$ in the device that we used (in a Rock-Eval the recording corresponds to the infrared signal directly proportional to the $\mathrm{CO}_{2}$ flux).

Using the procedure described previously, knowing the temperature of destabilisation of each characteristic peak of a single carbonate, we can determine the nature of this carbonate and knowing the amount of $\mathrm{CO}_{2}$ released by each carbonate, we can directly deduct the amount of the different carbonates present in the sample.

Indeed, knowing the $\mathrm{CO}_{2}$ mass released during destabilisation, $m\left(\mathrm{CO}_{2}\right)$, it is possible to deduce the mass of mineral carbon, $m(\mathrm{C})$, initially present in the sample:

$$
m(\mathrm{C})=\left[\mathrm{M}(\mathrm{C}) / \mathrm{M}\left(\mathrm{CO}_{2}\right)\right] m\left(\mathrm{CO}_{2}\right)=0.2729 m\left(\mathrm{CO}_{2}\right)
$$

$\mathrm{M}(\mathrm{C})$ being the atomic mass of carbon and $\mathrm{M}\left(\mathrm{CO}_{2}\right)$ being the molecular mass of $\mathrm{CO}_{2}$.

The mass concentration in $\%$ of mineral carbon is given by:

$$
\mathrm{wt} \%(\mathrm{C})=100[m(\mathrm{C}) / m(\text { sample })]
$$

with $m$ (sample) the mass of the analysed sample, the mass concentration in $\%$ of the different carbonates $(i)$ is thus given by:

$$
\mathrm{wt} \%(\text { carbonate } i)=\mathrm{wt} \%(\mathrm{C})[\mathrm{M}(\text { carbonate } i) / \mathrm{M}(\mathrm{C})]
$$

$\mathrm{M}$ (carbonate $i$ ) being the molecular mass of carbonate $i$.

\subsection{Application Example}

Figure 8 shows the results obtained with a synthetic mixture (50\% $-50 \%$ by weight) of two different pure carbonate standards (20 mg of magnesite, $20 \mathrm{mg}$ of calcite, e.g. total weight $40 \mathrm{mg}$ ). Following the method described above, we find that the surface area of the two peaks is indeed equivalent and we obtain a result of $50 \%$ of magnesite, $50 \%$ of calcite and $100 \%$ of total carbonate. Similar tests were done with several tens of different known mixtures and we always obtained a good match with an error of less than $1 \%$. 


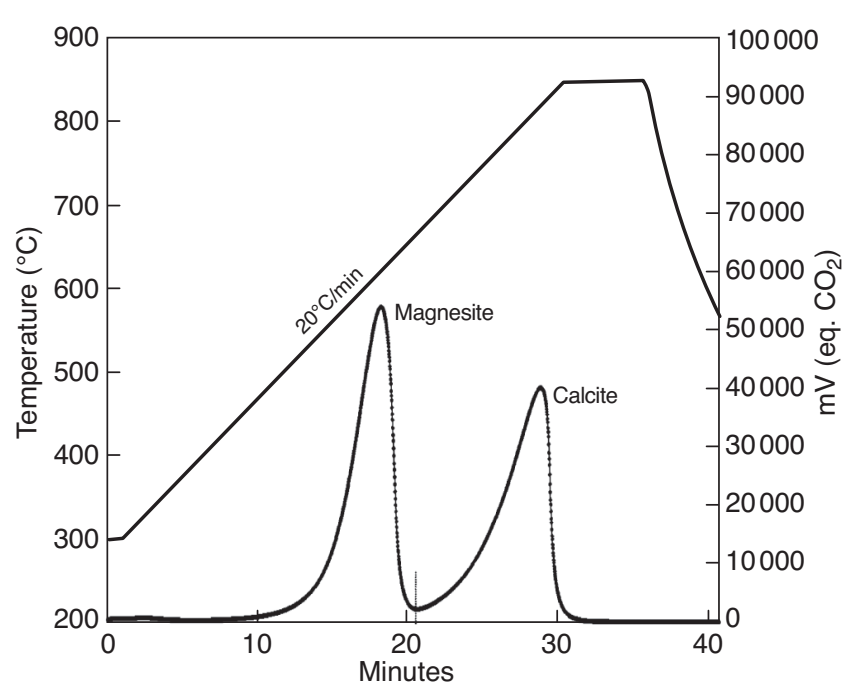

Figure 8

Results obtained with a synthetic mixture $(50 \%-50 \%$ by weight) of two different pure carbonate standards ( $20 \mathrm{mg}$ of magnesite, $20 \mathrm{mg}$ of calcite: total weight $40 \mathrm{mg}$ ). With the method used, we find that the surface area of the two peaks is indeed equivalent (see comments in the text).

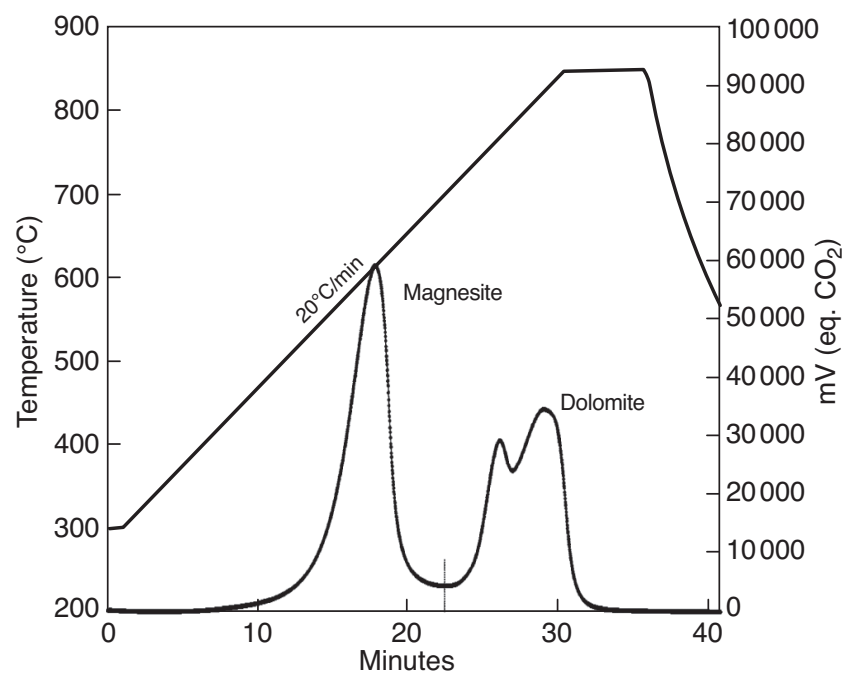

Figure 9

Results obtained on a real rock (carbonate vein of Oman). The method determines the carbonates and quantifies their respective contents (here: $49 \%$ of magnesite, $43 \%$ of dolomite and $8 \%$ of non-carbonate minerals; see comments in the text).
Figure 9 shows an example of application to a natural carbonate rock in a vein filling a fracture within the peridotite nappe of Oman. In this example, we can determine that the carbonates are a mixture of magnesite and dolomite (very characteristic by its double peak). The respective amounts can be determined easily by the proposed method. They are, in this example, $49 \%$ of magnesite, $43 \%$ of dolomite and $8 \%$ of non-carbonate minerals.

\section{CONCLUSION}

The method presented in this paper, using a standard Rock-Eval pyrolyser, allows a rapid characterisation and quantification of the whole range of carbonates in any kind of solid sample by monitoring the $\mathrm{CO}_{2}$ flux released during the progressive thermal destabilisation of the carbonated fraction. Indeed, using the oxidation cycle of the Rock-Eval, the characteristic peaks of destabilisation allow one to identify the different types of carbonates present in the analysed sample. The calibration characteristic profiles presented in this paper for the main natural carbonates as reference data show that copper carbonates are destabilised first, then iron carbonates, then manganese carbonates, then magnesium carbonates, then finally calcium carbonates. Complex carbonates such as dolomite and hydrated carbonates such as hydromagnesite show a signature with several peaks. Moreover, the quantification of each peak allows one to give the respective proportions of these different types of carbonates in the sample even in cases of mixing of different species as well as a quantification of the non-carbonated fraction. Finally, this simple method should find easy application in a wide range of disciplines, either academic or industrial.

\section{REFERENCES}

Al-Jaroudi S., Ul-Hamid A., Mohammed A.-R., Saner S. (2007) Use of X-ray powder diffraction for quantitative analysis of carbonate rock reservoir samples, Powder Technol. 175, 115-121.

Böke H., Akkurt S., Ozdemir S., Gôktürk E.H., Caner Saltik E.N. (2004) Quantification of $\mathrm{CaCO}_{3}-\mathrm{CaSO}_{3}-0.5 \mathrm{H}_{2} \mathrm{O}-\mathrm{CaSO}_{4} 2 \mathrm{H}_{2} \mathrm{O}$ mixtures by FTIR analysis and its ANN model, Mater. Lett. 58, 723-726.

Bosch R.F., Gimeno A.J.V., Moreno M.M. (2002) FT-IR quantitative analysis of calcium carbonate (calcite) and silica (quartz) mixtures using the constant ration method. Application to geological samples, Talanta 58, 811-821. doi:10.1016/S0039-9140(02)00372-7.

Cebulak S., Langier-Kuniarowa A., Czapowsk G., Bzowska G. (2003) New aspects of TA application for studies of Ca-Mg carbonate minerals exemplified by upper Permian rocks, J. Therm. Anal. Calorim. 72, 405-411.

Diebold F.E., Lemish J., Hiltrop C. (1963) Determination of calcite, dolomite, quartz and clay content of carbonate rocks, J. Sediment. Res. 33, 1, 124-139.

Gavish E., Friedman G.M. (1973) Quantitative analysis of calcite and $\mathrm{Mg}$-calcite by X-ray diffraction: Effect of grinding on peak height and peak area, Sedimentology 20, 437-444.

Hillier S., Suzuki K., Cotter-Howells J. (2001) Quantitative determination of cerussite (lead carbonate) by X-ray powder diffraction and inferences for lead speciation and transport in stream sediments from a former lead mining area in Scotland, Appl. Geochem. 16, 597-608. 
Lafargue E., Marquis F., Pillot D. (1998) Rock-Eval 6 applications in hydrocarbon exploration, production and soil contamination studies, Oil Gas Sci. Technol. - Rev. IFP 53, 4, 421-437.

Legodi M.A., de Waal D., Potgieter J.H., Potgieter S.S. (2001) Technical note rapid determination of $\mathrm{CaCO}_{3}$ in mixtures utilising FT-IR spectroscopy, Miner. Eng. 14, 1107-1111.

Martinez B., Plana F. (1987) Quantitative X-Ray diffraction of carbonate sediments: Mineralogical analysis through fitting of Lorentzian profiles to diffraction peaks, Sedimentology 34, 1, 169-174.

Pillot D., Deville E., Prinzhofer A. (2011) Méthode pour la caractérisation et la quantification rapides des carbonates d'un matériau solide, Brevet déposé à l'Institut National de la Propriété Industrielle le 18 mars 2011, référence $n^{\circ} 11 / 00.841$.

Roselle P. (1982) Quantitative mineralogical analysis of carbonate sediments by X-ray diffraction: a new, automatic method for sediments with low carbonate content, Sedimentology 29, 4, 595-600.

Siewert C. (2004) Rapid screening of soil properties using thermogravimetry, Soil Sci. Soc. Am. J. 68, 1656-1661.
Tatzber M., Stemmer M., Spiegel H., Katzlberger C., Haberhauer G., Gerzabek M.H. (2007) An alternative method to measure carbonate in soils by FT-IR spectroscopy, Environ. Chem. Lett. 5, 9-12. doi:10.1007/s10311-006-0079-5.

Vagenas N.V., Gatsouli A., Kontoyannis C.G. (2003) Quantitative analysis of synthetic calcium carbonate polymorphs using FT-IR spectroscopy, Talanta 59, 831-836.

Villain G., Thiery M., Platret G. (2007) Measurement methods of carbonation profiles in concrete: Thermogravimetry, chemical analysis and gammadensimetry, Cem. Concr. Res. 37, 1182-1192. doi:10.1016/j.cemconres.2007.04.015.

Weber J.N. (1968) Quantitative Mineralogical Analysis of Carbonate Sediments: Comparison of X-ray Diffraction and Electron Probe Microanalyzer Methods, J. Sediment. Res. 38, 232-234. doi: 10.1306/74D7192E-2B21-11D7-8648000102C1865D.

Final manuscript received in May 2012 Published online in February 2013 or distributed for profit or commercial advantage and that copies bear this notice and the full citation on the first page. Copyrights for components of this work owned by others than IFP Energies nouvelles must be honored. Abstracting with credit is permitted. To copy otherwise, to republish, to post on servers, or to redistribute to lists, requires prior specific permission and/or a fee: Request permission from Information Mission, IFP Energies nouvelles, fax. +33147527096, or revueogst@ifpen.fr. 